\title{
EVALUATION OF A SINGLE SPRINKLER UNDER EGYPTIAN MICROCLIMATE CONDITIONS
}

\author{
Sehsah, E.M.E* and M.M El Baily** and M. Aiad***
}

\begin{abstract}
Single leg tests were conducted to determine performance of two different sprinkler that can be used in impact sprinkler irrigation systems design operating at 100, 200 and $300 \mathrm{kPa}$. The different two sprinklers HS2803 and Gardena impulse sprinkler were tested for coefficient of uniformity (CU), soil moisture content (MC) and EC (electrical conductivity) at three different pressure points for two different microclimate screen greenhouse and no tillage field conditions. As well as the experimental carried out at three different riser height of the sprinkler $0.6 \mathrm{~m}, 1.0 \mathrm{~m}$ and $1.2 \mathrm{~m}$. Radial leg tests have been previously performed to find the water distribution pattern. Afterwards both outdoor single-sprinkler irrigation tests have been also performed to know the water distribution pattern distorted by microclimate conditions spatially the wind action. Results show that the main factors to be controlled are: the wind speed, the sprinkler type and the riser height. Results showed that higher Coefficients of Uniformity (CU) are attained with HS2803 three armed sprinkler than with a single impulse sprinkler under low wind speeds in screen greenhouse. As well as, the maximum values of coefficient uniformity $C U$ percent under screen greenhouse conditions were 93.7\% and $89.5 \%$ for HS2803 and Gardena impulse sprinkler at 300 $\mathrm{kPa}$ respectively. The soil moisture contents at $300 \mathrm{kPa}$ operating pressure and 0.6 riser height under field conditions were $39.6 \%$ compared to 26.7 for HS2803 sprinkler and Gardena impulse sprinkler respectively. The soil conductivity (EC) at $300 \mathrm{kPa}$ operating pressure under field conditions were $2.1 \mathrm{cmSm}-1,2.4 \mathrm{cmSm}-1$ and $2.6 \mathrm{cmSm}-1$ compared to $3.9 \mathrm{cmSm}-1,4.1 \mathrm{cmSm}-1$ and $4.4 \mathrm{cmSm}-1$ for HS2803 sprinkler and Gardena impulse sprinkler respectively.
\end{abstract}

KEYWORDS: Coefficient of Uniformity, Sprinklers, Irrigation Uniformity

\footnotetext{
*Associate. Prof Dr., Dept. of Agric. Eng. Faculty of Agricultural, Kafr El-Sheikh University, 33516-kafr El-Sheikh, Egypt E-Mail sehsah_2000@yahoo.de

**Researcher Dr., Agric. Eng. Institute, A.R.C. Egypt ****Researcher Dr, Soil water and environment A.R.C., Egypt
} 


\section{INTRODUCTION}

ost sprinkle irrigation systems require a minimum value of
water distribution uniformity (Christiansen's Coefficient of
Uniformity (CU) $80 \%$ ) (Keller and Bliesner, 1990). Low values of $\mathrm{CU}$ are usually indicators of a faulty combination of the number and size of nozzles, working pressure and spacing of sprinklers. The process of water application in solid set systems mainly depends on the sprinkler distribution model (determined by the sprinkler design itself, the number and type of nozzles and the working pressure), the sprinkler layout and the wind. Together with these factors, there are others less relevant in the distribution of water, such as: the length of irrigation, riser height of the sprinkler, discharge angle, etc (Tarjuelo et al., 1992). A larger duration of irrigation favors uniformity, as this partly compensates wind distortions since the wind varies along the time (Tarjuelo, 1999; Montero, 1999). To determine Christiansen's Coefficient of Uniformity (CU) (Christiansen, 1942) and other parameters characterizing surface water distribution, we need to know the application rate caught in a grid of cans within the wetted area. The procedures to determine sprinkler water distribution can be grouped into three types:

a) To apply the catch cans grid to the existing irrigation system: evaluation of the system (Merriam and Keller, 1978; Merriam et al., 1980, Brito, R. A. L., and L. S. Willardson. 1982, Li, J., and M. Rao. 2003, Li, J., B. Li, and M. Rao. 2005, Martin. 2003).

b) To reduce the catch cans grid to a single-leg in a radial pattern, in nowind and with high relative humidity conditions. The application rate can be calculated by rotating the radial pattern around the sprinkler (Vories and Von Bernuth, 1986, Perry, C., and M. D. Dukes. 2004). The first procedure allows us to know the working conditions of an existing irrigation system. The second one1 has the advantage of knowing the entire water distribution pattern of the sprinkler, as well as uniformity parameters under any irrigation spacing. Nevertheless, the problem of changing environmental conditions during the test is Highlighted (e.g. wind direction and speed, evaporation, etc.). To this must be added changing evaporation in the catch cans, depending on 
their location at the center or on the edges of the wetted pattern. The third one has the advantage of controlling all factors in the process, especially sprinkler water distribution, thus allowing us to establish comparisons between different sprinklers. Environmental parameters such as temperature, RH, leaf wetness or moisture affect various stages of the late blight pathogen cycle and disease development. Temperature affects sporangial germination (Mizubuti and Fry, 1998), infection and lesion expansion rate (Hartill et al., 1990, Schneider, A. D. 2000

), sporulation (Sato, 1994). Water in the form of rainfall, condensation, or $\mathrm{RH}$ is important for late blight development. However, the effect of irrigation management treatments on microclimate and potential late blight development as quantified by simulated late blight severity values has not been adequately documented. Potato crop is very sensitive to water stress, and total available soil water should not be depleted by more than $30-50 \%$ to optimize yields (Fabeiro et al., 2001). The demand for efficient use of water and improved production practices for the region makes the evaluation of efficient alternative irrigation systems such as surface and sub-surface drip irrigation important. There is little quantitative data on the impact of irrigation treatments on microclimate and late blight potential on the potato crop in the cool, humid region of North America. An assessment of the effects of various irrigation systems on microclimate would be greatly beneficial to our understanding and management of the disease in cool and hoot humid regions.

\section{OBJECTIVES}

The main objectives of the present study are to evaluate the two different sprinkler in spray irrigation system, as well as found the recommendations for helping about design and management of sprinkle irrigation. As well as, to determine the effects of irrigation systems in microclimatic on parameters influencing the potential for late blight development

\section{MATERIALS AND METHODS}

In order to determine the main factors that affect the water application at field level using solid set systems (experimental plots), more than 200 tests have been carried out with two different types of sprinkler nozzle pressure. Two different types of sprinklers, HS2803 
three arms plastic and Gardena impulse sprinkler were used to evaluate under Egyptian climate conditions. As well as, the three riser pipe heights $0.6 \mathrm{~m}, 1 \mathrm{~m}$ and $1.2 \mathrm{~m}$ were tested at $100 \mathrm{kPa}, 200 \mathrm{kPa}$ and $300 \mathrm{kPa}$ operating working pressures. An impact impulse sprinkler (Gardena) Irrigate up to $15 \mathrm{~m}$ around perimeter with 30-360 degree swivel range was used under all treatment conditions. The Sprinkler three arms new design model HS2803 Sprinkler is high impact plastic sprinkler $100 \%$ pure material PP products shown in figure 1 (a). The size of sprinkler is $20.5 \times 19 \times 9.5 \mathrm{~cm}$ with steering wheel design sprinkler and 360 degree rotating. To determine the sprinkler water distribution radial profile in nowind and high relative humidity conditions, the following standards were adopted: ASAE.S.330.1 (1985), ASAE.S.398.1 (1985) and UNE 68-07286 (1986). Two types of outdoor tests were conducted: single sprinkler and block irrigation tests. Moisture Meter type $\mathrm{HH} 2$ used to measure the soil moisture content shown in figure 1 (b). Readings are displayed on the LCD and stored to memory for later download to a PC. The sensor is able to measure within a measuring range of 5 - 55 volumetric moisture content with an accuracy of $5 \%$ with standard calibration and only $2 \%$ with soil specific calibration.

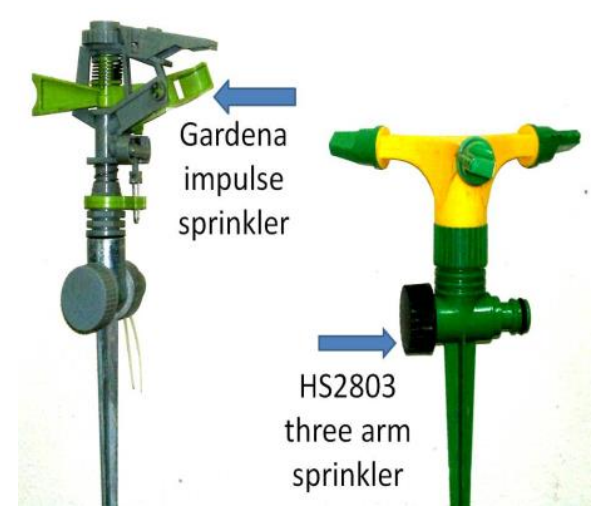

(a)

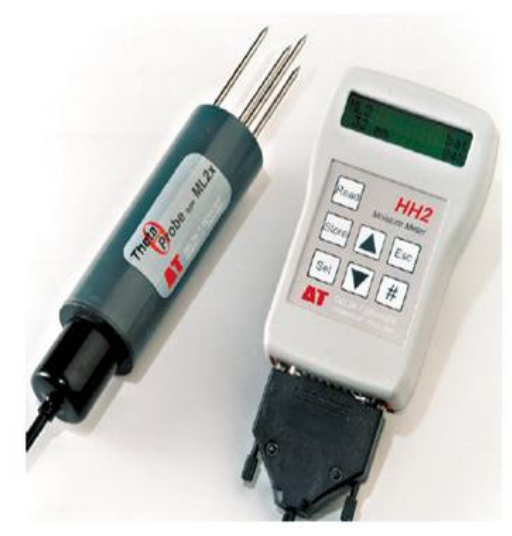

(b)

Fig. 1: The two sprinklers (a) and HH2 meter measured the soil moisture content and the soil conductivity (b).

Field measurements were conducted at kafr El Sheikh University and the Sakha Experimental Station, Egypt. The two different micro-climate 
conditions, flat roof screen-house and open field (no-tillage)) loam soil field were prepared to test the two sprinklers. The flat roof screengreenhouse dimensions were $40 \mathrm{~m}$ length, $20 \mathrm{~m}$ width, $2.5 \mathrm{~m}$ height made of steel screen. The open field (no-tillage) loam soil was not irrigated for four months and it is dimension $60 \mathrm{~m}$ width and $200 \mathrm{~m}$ length. As well as, the open field (no-tilled) area was divided into two parts to evaluate the sprinklers. The soil mechanical analysis of the screen greenhouse and non-cultivated soil illustrated as shown in tables 1 and 2. The suggested wind speed and other climate limitations were measured online with computerized weather station WS2300 that connected to recording and saved the climate data in a file directly. The weather station WS2300 was fixed in the screen greenhouse and non-cultivated field to measure the microclimate conditions. All experimental started from 10 April 2012 to end of March 2012. The Plastic catch cans $25 \mathrm{~cm}$ length $15 \mathrm{~cm}$ width 5 $\mathrm{cm}$ depth grid to a single-leg in a radial pattern, in no-wind and with high relative humidity conditions as shown in figure 2 . As well as the distance between every can was $50 \mathrm{~cm}$ for $15 \mathrm{~m}$ long radial pattern. The Techom water volume meter and stop watch was used to measure the application spray irrigation flow rate for both sprinkler. The pressure gauge manometer with the regular control valves was used to obtain and adjust the different operating pressures. As well as the soil moisture content and soil conductivity were measured by using the HH2 (TDR) instrument. As well as the Oven method was used to calibrate of $\mathrm{HH} 2$ instrument at different soil layers. The soil moisture content for both screen greenhouse and no tillage field before irrigated was measured and listed in table 1 for every treatment plot of irrigated soil. The duration irrigation time for each treatment was fixed at $30 \mathrm{~min}$. Also, the mechanical analysis for screen greenhouse and fields' soil were listed in table 2 and 3.

\section{Coefficient of uniformity (CU) determination}

The coefficient of uniformity of each sprinkler test was assessed, using Eq. (1), (2) and (3) adopted from Eq.1, where CU is the coefficient of uniformity of the sprinkler under test, D is the average absolute deviation from the mean, $\mathrm{M}$ is the mean application rate, $\mathrm{Xi}$ is the individual application amount in the catch can, $\mathrm{n}$ is the number of individual application amounts and $\Sigma$ is the symbol for summation.

$$
\begin{aligned}
& \mathrm{CU}=100(1-\mathrm{D} / \mathrm{M}) \ldots \ldots . .1 \\
& \mathrm{D}=(1 / \mathrm{n}) \Sigma|\mathrm{Xi}-\mathrm{M}| \ldots \ldots . .2
\end{aligned}
$$




$$
M=(1 / n) \sum X i \ldots \ldots \ldots \ldots . . .3
$$

Table 1: The soil moisture content percent for screen greenhouse and no tillage field before irrigation at $10 \mathrm{~cm}$ depth under all treatment conditions.

\begin{tabular}{|c|c|c|c|c|c|}
\hline \multirow{2}{*}{$\begin{array}{c}\text { Operating } \\
\text { pressure, } \\
\mathrm{kPa}\end{array}$} & $\begin{array}{c}\text { Riser } \\
\text { height, } \\
\mathrm{cm}\end{array}$ & $\begin{array}{c}\text { coil moisture } \\
\text { contents in Screen } \\
\text { Greenhouse, \% }\end{array}$ & \multicolumn{2}{c|}{$\begin{array}{c}\text { Soil moisture } \\
\text { contents in field (no } \\
\text { tiled soil) \% }\end{array}$} \\
\cline { 3 - 6 } & $\begin{array}{c}\text { Gardena } \\
\text { Sprinkler }\end{array}$ & $\begin{array}{c}\text { HS2803 } \\
\text { Sprinkler }\end{array}$ & $\begin{array}{c}\text { Gardena } \\
\text { Sprinkler }\end{array}$ & $\begin{array}{c}\text { HS2803 } \\
\text { Sprinkler }\end{array}$ \\
\hline 100 & 60 & 9.85 & 13.0 & 10.1 & 10.3 \\
\hline & 100 & 12.1 & 12.1 & 9.6 & 11.9 \\
\hline & 120 & 12.9 & 10.2 & 8.8 & 10.3 \\
\hline 200 & 60 & 10.5 & 11.3 & 8.1 & 11.2 \\
\hline & 100 & 13.5 & 12.5 & 10.3 & 9.7 \\
\hline & 120 & 11.2 & 10.5 & 11.1 & 25.6 \\
\hline 300 & 60 & 12.1 & 9.8 & 9.7 & 9.1 \\
\hline & 100 & 10.1 & 11.4 & 8.2 & 10.3 \\
\hline & 120 & 11.1 & 14.2 & 8.8 & 10.6 \\
\hline
\end{tabular}

Table 2 : The soil mechanical analysis of the screen greenhouse

\begin{tabular}{|l|c|c|c|c|}
\hline \multirow{2}{*}{$\begin{array}{c}\text { Soil depth, } \\
\mathrm{cm}\end{array}$} & \multicolumn{4}{|c|}{ Particle size distribution } \\
\cline { 2 - 5 } & Sand, \% & Silt, \% & Clay,\% & Clays, $\%$ \\
\hline $0-15$ & 21.7 & 31.5 & 46.8 & clayey \\
\hline $15-30$ & 21.4 & 30.4 & 48.2 & clayey \\
\hline $30-45$ & 18.4 & 29.8 & 51.8 & clayey \\
\hline $45-60$ & 19.9 & 28.9 & 51.2 & clayey \\
\hline Mean & 20.3 & 30.2 & 49.5 & clayey \\
\hline
\end{tabular}

Table 3 : listed the soil mechanical analysis of the non cultivation field

\begin{tabular}{|l|c|c|c|c|}
\hline \multirow{2}{*}{$\begin{array}{c}\text { Soil depth, } \\
\text { cm }\end{array}$} & \multicolumn{4}{|c|}{ Particle size distribution } \\
\cline { 2 - 5 } & Sand, \% & Silt, $\%$ & Clay, $\%$ & Clays, $\%$ \\
\hline $0-15$ & 16.56 & 23.00 & 60.44 & clayey \\
\hline $15-30$ & 17.57 & 25.07 & 57.36 & clayey \\
\hline $30-45$ & 18.14 & 20.52 & 60.74 & clayey \\
\hline $45-60$ & 18.28 & 24.88 & 56.84 & clayey \\
\hline Mean & & & & clayey \\
\hline
\end{tabular}



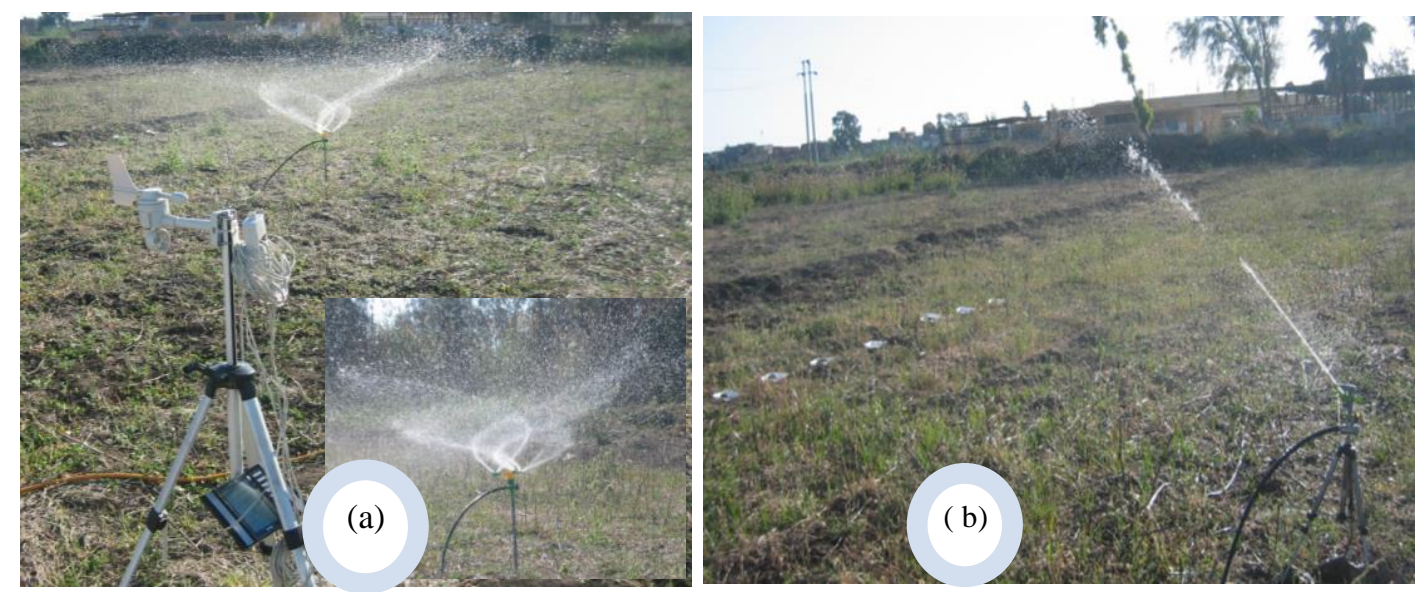

Fig.2: Display the two different types of sprinklers, (a) HS2803 three armed and (b) Gardena impulse sprinkler evaluated under no tillage soil field conditions.

\section{RESULTS AND DISCUSSIONS}

The result of the current investigation research presented that the type of sprinkler, operating pressure and riser height were a highly significant effect on the different irrigation parameters such as (CU), (MC) and (EC). Also, the operating pressure, riser height and microclimate conditions effect on the above irrigation parameters under two different location greenhouse and the open (no-tillage) field conditions.

\section{Coefficient uniformity (CU)}

The study showed that there was a significant difference $(p<0.05)$ in coefficient uniformity (CU) values between Gardena impulse and HS2803 three arm sprinkler at different pressure levels as shown in figure 3. The HS2803 sprinkler gave high values of CU percent compared to the Gardena impulse sprinkler. This may be attributed to the quality of Gardena impulse made sprinklers which have numerous defects in casting, washers, spring and screw machined parts. As well as the increasing of riser height tends to decrease the $\mathrm{CU}$ percent values under two different microclimate conditions screen greenhouse and the open field. The maximum values of coefficient uniformity $\mathrm{CU}$ percent under screen greenhouse microclimate conditions were $93.7 \%$ and $89.5 \%$ for HS2803 and Gardena impulse sprinkler at $300 \mathrm{kPa}$ respectively. Also, the 
maximum values of coefficient uniformity (CU) percent under field conditions were $90.1 \%$, and $82.8 \%$ for HS2803 and Gardena impulse sprinkler at $300 \mathrm{kPa}$ operating pressure respectively. The above result of (CU) may be due to the different water losses in open field compared to greenhouse such as wind speeds and microclimate conditions. Figure 3 indicate also the effect of operating pressure on the coefficient uniformity (CU), the increasing of the operating pressure tends to increase of the coefficient uniformity under all treatment conditions. The operating pressure $300 \mathrm{kPa}$ gave the high values of coefficient uniformity compared to the low operating pressure $100 \mathrm{kPa}$ for both different sprinkler types HS2803 and Gardena impulse. The values of coefficient uniformity under open (no-tillage) field microclimate conditions were $87.1 \%, 90 \%$ and $90.1 \%$ for HS2803 sprinkler compared to $80.9 \%, 82.1$ and $82.8 \%$ for Gardena impulse sprinkler at $100 \mathrm{kPa}, 200 \mathrm{kPa}$ and $300 \mathrm{kPa}$ respectively. The values of coefficient uniformity under screen greenhouse microclimate conditions were 91.6\%, $92 \%$ and $93.6 \%$ for HS2803 sprinkler compared to $86.5 \%, 87.8$ and $89.9 \%$ for Gardena impulse sprinkler at $100 \mathrm{kPa}, 200 \mathrm{kPa}$ and $300 \mathrm{kPa}$ respectively. The riser heights $0.6 \mathrm{~m}, 1 \mathrm{~m}$ and $1.2 \mathrm{~m}$ were significant effect on the coefficient uniformity (CU) for HS2803 sprinkler under screen greenhouse and field conditions as shown in figure 3. On the other hand, the above riser's height gave significant effect on the coefficient uniformity (CU) for HS2803 sprinkler under field conditions at low and highly values of operating pressure. As well as, the riser heights $0.6 \mathrm{~m}, 1 \mathrm{~m}$ and $1.2 \mathrm{~m}$ were significant effect on the coefficient uniformity (CU) for the Gardena impulse sprinkler under field conditions at low and highly values of operating pressure. As well as, the results showed that the all the tested sprinklers passed the $15 \mathrm{~m} \mathrm{x}$ $15 \mathrm{~m}$ layout test at $300 \mathrm{kPa}$ pressure level for HS2803 sprinkler compared to $12.8 \times 12.8$ layout test at $300 \mathrm{kPa}$ pressure for Gardena impulse sprinkler. This means the layout can be adopted for design purposes under Egyptian conditions, leading to a reduction in operational costs of the spray line. It noticed that wind speed effected on the CU percent under field and greenhouse conditions. The CU values for both sprinklers were higher than in greenhouse compared to the values of $\mathrm{CU}$ in field conditions. The above result may be due to the increasing of wind speed 
under field conditions. As shown in tables 4 and 5, the recorded maximum values of wind speed at $100 \mathrm{kPa}$ operating pressure and 0.6 riser heights were $5.9 \mathrm{~m} \mathrm{~s}^{-1}$ and $1.4 \mathrm{~m} \mathrm{~s}^{-1}$ under screen greenhouse and the field conditions respectively. The average values of RH were $79.8 \%$ and $56.7 \%$ for greenhouse and field conditions respectively.

\section{Soil moisture content (MC)}

The result indicated that the type of sprinkler, riser height, and operating pressure under two different microclimate conditions effected on the soil moisture contents (MC) percent. The HS2803 sprinkler produced high values of the soil moisture contents compared to the Gardena impulse sprinkler under al treatment conditions. The soil moisture contents at 300 $\mathrm{kPa}$ operating pressure under field conditions were $39.6 \%, 34.2 \%$ and $30.8 \%$ for HS2803 sprinkler compared to $26.7 \%, 25.2 \%$ and $20.8 \%$ for Gardena impulse sprinkler at $0.6 \mathrm{~m}, 1 \mathrm{~m}$ and $1.2 \mathrm{~m}$ riser height respectively. Also, the same trends were fund under screen greenhouse conditions. It's noticed that the microclimate under screen greenhouse effect on the soil moisture contents due to increase of inside temperature and RH compared to the field conditions. The maximum air temperature was $48{ }^{\circ} \mathrm{C}$ in screen greenhouse compared to $29.5{ }^{\circ} \mathrm{C}$ under field conditions. It means also, there are the losses in the applied water of spray irrigation due to increase of the values of microclimate conditions such as the air temperature, relative humidity and change of air direction as shown in tables 4 and 5. Also, the increase of riser height tends to reduce the soil moisture contents under all treatment conditions. The maximum soil moisture contents for HS2803 sprinkler under field conditions at $300 \mathrm{kPa}$ operating pressure were $39.6 \%, 34.2 \%$ and 30.8 $\%$ for $0.6 \mathrm{~m}, 1 \mathrm{~m}$ and $1.2 \mathrm{~m}$ riser height respectively. The same results were found under screen greenhouse conditions for Gardena impulse sprinkler. As well as, the operating pressure gave the significant effect on the soil moisture contents. The increase of operating pressure tends to increase of soil moisture contents under all treatment conditions as shown in table 6. The soil moisture contents for Gardena impulse sprinkler were $19.4 \%, 20.5 \%$ and $22.6 \%$ under screen greenhouse condition compared to $20.6 \%, 24.1 \%$ and $26.7 \%$ under field condition at $100 \mathrm{kPa}, 200 \mathrm{kPa}$ and $300 \mathrm{kPa}$ respectively. Also, the soil moisture 
contents for HS2803 sprinkler were $23 \%, 28.8 \%$ and $29.8 \%$ under screen greenhouse condition compared to $24.1 \%, 29.2 \%$ and $39.6 \%$ under field condition at $100 \mathrm{kPa}, 200 \mathrm{kPa}$ and $300 \mathrm{kPa}$ respectively. It is found that the HS2803 sprinkler may be able to give the high values of soil moisture content after one hour compared to the Gardena sprinkler at 0.6 riser height and $300 \mathrm{kPa}$ operating pressure as shown in figure 4 . This result may be obtained on the sprinkler flow rate that produced from each sprinkler. The HS2803 sprinkler produced the high values of flow rate compared to Gardena Sprinkler as shown in table 7. As well as, the increase of riser height tends to decrease of the sprinkler flow rate for both sprinklers as shown in table 7. On the other hand, the increasing of operating pressure tends to increase the sprinkler flow rate. The HS2803 sprinkler produced $14.11 \mathrm{~m}^{-1}$ at $0.6 \mathrm{~m}$ riser height and $300 \mathrm{kPa}$ operating pressure under field conditions. This result may be able to reduce the air temperature and increasing of water volume in soil profile. The flow rate under screen greenhouse and open field were controlled by using the electronic Gardena PC programming water flow meter.

\section{Soil conductivity}

Table 8 Indicated that the effect of type of sprinkler, different operating pressure and riser height on soil conductivity under greenhouse and field conditions. It is noticed that the HS2803 sprinkler gave low values of soil conductivity compared to Gardena impulse sprinkler. Therefore the HS2803 produced the high values for both soil moisture content percent and flow rate under all treatment conditions. The result indicated that the type of sprinkler, riser height, and operating pressure under two different microclimate conditions affected on the soil conductivity (EC). The HS2803 sprinkler produced low values of the soil conductivity (EC) compared to the Gardena impulse sprinkler under all treatment conditions. The above result may be due to the water volume increased in soil profile by using the HS2803 sprinkler. The soil conductivity (EC) at $300 \mathrm{kPa}$ operating pressure under field conditions were $2.1 \mathrm{cmSm}^{-1}, 2.4$ $\mathrm{cmSm}^{-1}$ and $2.6 \mathrm{cmSm}^{-1}$ compared to $3.9 \mathrm{cmSm}^{-1}, 4.1 \mathrm{cmSm}^{-1}$ and 4.4 
$\mathrm{cmSm}^{-1}$ for HS2803 sprinkler and Gardena impulse sprinkler respectively. Also, the same trends were fund under screen greenhouse conditions. It noticed that the soil conductivity (EC) depending on water in the soil and soil moisture contend may be also depending on the microclimate conditions. Due to increase of the inside temperature under screen greenhouse compared to the field conditions, the EC values may be gave the high values of $\mathrm{EC}$ in the soil of greenhouse. The maximum air temperature was recorded at $48{ }^{\circ} \mathrm{C}$ in screen greenhouse compared to $29.5{ }^{\circ} \mathrm{C}$ under field conditions. It is found that the HS2803 sprinkler may be able to give the low values of soil conductivity after a few minutes compared to the Gardena sprinkler at 0.6 riser height and $300 \mathrm{kPa}$ operating pressure because the water volume in soil profile will be increased as shown in figure 5.

Table 4: The microclimate conditions in Screen greenhouse

\begin{tabular}{|c|c|c|c|c|c|c|c|c|c|}
\hline \multirow{2}{*}{$\begin{array}{c}\text { Pressure } \\
\text { k Pa }\end{array}$} & \multirow{2}{*}{$\begin{array}{l}\text { Riser } \\
\text { heigh } \\
t \text { cm }\end{array}$} & \multicolumn{4}{|c|}{ Gardena Sprinkler } & \multicolumn{4}{|c|}{ HS Sprinkler } \\
\hline & & $\begin{array}{c}\text { In } \\
\text { Temp } \\
{ }^{\text {oC }} \mathbf{C}\end{array}$ & $\begin{array}{c}\text { Out. } \\
\text { Temp. } \\
{ }^{\circ} \mathrm{C} \\
\end{array}$ & $\begin{array}{c}\text { Wind } \\
\text { Speed } \\
\mathrm{m} \mathrm{s}^{-1} \\
\end{array}$ & $\begin{array}{l}\text { Wind } \\
\text { direct, } \\
\text { degree }\end{array}$ & $\begin{array}{c}\text { In } \\
\text { Temp. } \\
{ }^{\circ} \mathbf{C} \\
\end{array}$ & $\begin{array}{c}\text { Out. } \\
\text { Temp. } \\
{ }^{\circ} \mathrm{C} \\
\end{array}$ & $\begin{array}{c}\text { Wind } \\
\text { Speed } \\
\mathbf{s}^{-1} \\
\end{array}$ & $\begin{array}{r}\text { Wind } \\
\text { direct, } \\
\text { degree }\end{array}$ \\
\hline 100 & 60 & 47.0 & 29.7 & 1.4 & 315 & 47.5 & 29.7 & 2.4 & 312 \\
\hline 100 & 100 & 44.0 & 24.8 & 2.8 & 289 & 44.0 & 24.8 & 1.8 & 247 \\
\hline 100 & 120 & 44.0 & 28.5 & 2.4 & 289 & 48.0 & 28.5 & 1.3 & 260 \\
\hline 200 & 60 & 44.0 & 29.6 & 1.2 & 315 & 47.5 & 32.0 & 1.4 & 260 \\
\hline 200 & 100 & 44.0 & 28.0 & 1.1 & 315 & 44.0 & 24.0 & 1.7 & 312 \\
\hline 200 & 120 & 44.0 & 28.0 & 1.8 & 315 & 48.0 & 24.2 & 2.7 & 312 \\
\hline 300 & 60 & 43.0 & 31.8 & 1.9 & 247 & 48.3 & 33.4 & 2.3 & 247 \\
\hline 300 & 100 & 45.0 & 29.0 & 1.2 & 247 & 48.3 & 33.4 & 2.2 & 260 \\
\hline 300 & 120 & 42.0 & 29.0 & 1.3 & 247 & 48.0 & 24.2 & 2.5 & 260 \\
\hline 300 & 60 & 46.0 & 31.8 & 1.9 & 247 & 48.3 & 33.4 & 2.3 & 247 \\
\hline
\end{tabular}


Table 5: Display the microclimate conditions in open field no tillage soil conditions

\begin{tabular}{|c|c|c|c|c|c|c|c|}
\hline \multirow{2}{*}{$\begin{array}{c}\text { Pressur } \\
\text { e k Pa }\end{array}$} & $\begin{array}{c}\text { Riser } \\
\text { height } \\
\text { cm }\end{array}$ & \multicolumn{3}{|c|}{ Gardena Sprinkler } & \multicolumn{3}{|c|}{ HS2803 Sprinkler } \\
\cline { 3 - 8 } & & $\begin{array}{c}\text { Temp. } \\
{ }^{\circ} \mathrm{C}\end{array}$ & $\begin{array}{c}\text { Wind } \\
\text { Speed } \\
\mathrm{m} \mathrm{s}^{-1}\end{array}$ & $\begin{array}{c}\text { Wind } \\
\text { direct. } \\
\text { degree }\end{array}$ & $\begin{array}{c}\text { Temp. } \\
{ }^{\circ} \mathrm{C}\end{array}$ & $\begin{array}{c}\text { Wind } \\
\text { speed } \\
\mathrm{m} \mathrm{s}^{-1}\end{array}$ & $\begin{array}{c}\text { Wind } \\
\text { direct. } \\
\text { Degree }\end{array}$ \\
\hline 100 & 60 & 29.7 & 5.9 & 308 & 32.0 & 5.1 & 260 \\
100 & 100 & 24.8 & 5.7 & 300 & 24.0 & 5.6 & 312 \\
100 & 120 & 28.5 & 5.3 & 300 & 24.2 & 5.1 & 312 \\
200 & 60 & 29.7 & 4.2 & 270 & 33.4 & 4.1 & 312 \\
200 & 100 & 24.8 & 4.6 & 308 & 33.4 & 5.2 & 312 \\
200 & 120 & 28.5 & 4.5 & 308 & 24.2 & 5.7 & 309 \\
300 & 60 & 31.8 & 4.1 & 270 & 29.7 & 4.3 & 260 \\
300 & 100 & 28.7 & 4.4 & 270 & 24.8 & 4.6 & 312 \\
300 & 120 & 28.7 & 3.9 & 270 & 28.5 & 4.3 & 312 \\
\hline
\end{tabular}

\section{Summary and conclusions}

The results concluded that the, the wind speed may be affected on the $\mathrm{CU}$ percent under field than compared to greenhouse conditions. Also, The HS2803 sprinkler gave high values of CU and MC percent compared to the Gardena impulse sprinkler. The CU values for both sprinklers were higher than in greenhouse compared to the values of $\mathrm{CU}$ in field conditions. It's noticed that the microclimate under screen greenhouse effect on the soil moisture contents due to increase of inside temperature and $\mathrm{RH}$ compared to the field conditions. As well as, the type of sprinkler, riser height, and operating pressure under two different microclimate conditions affected on the soil conductivity (EC) percent. The HS2803 sprinkler may be able to give the low values of soil conductivity after a few minutes compared to the Gardena sprinkler. 

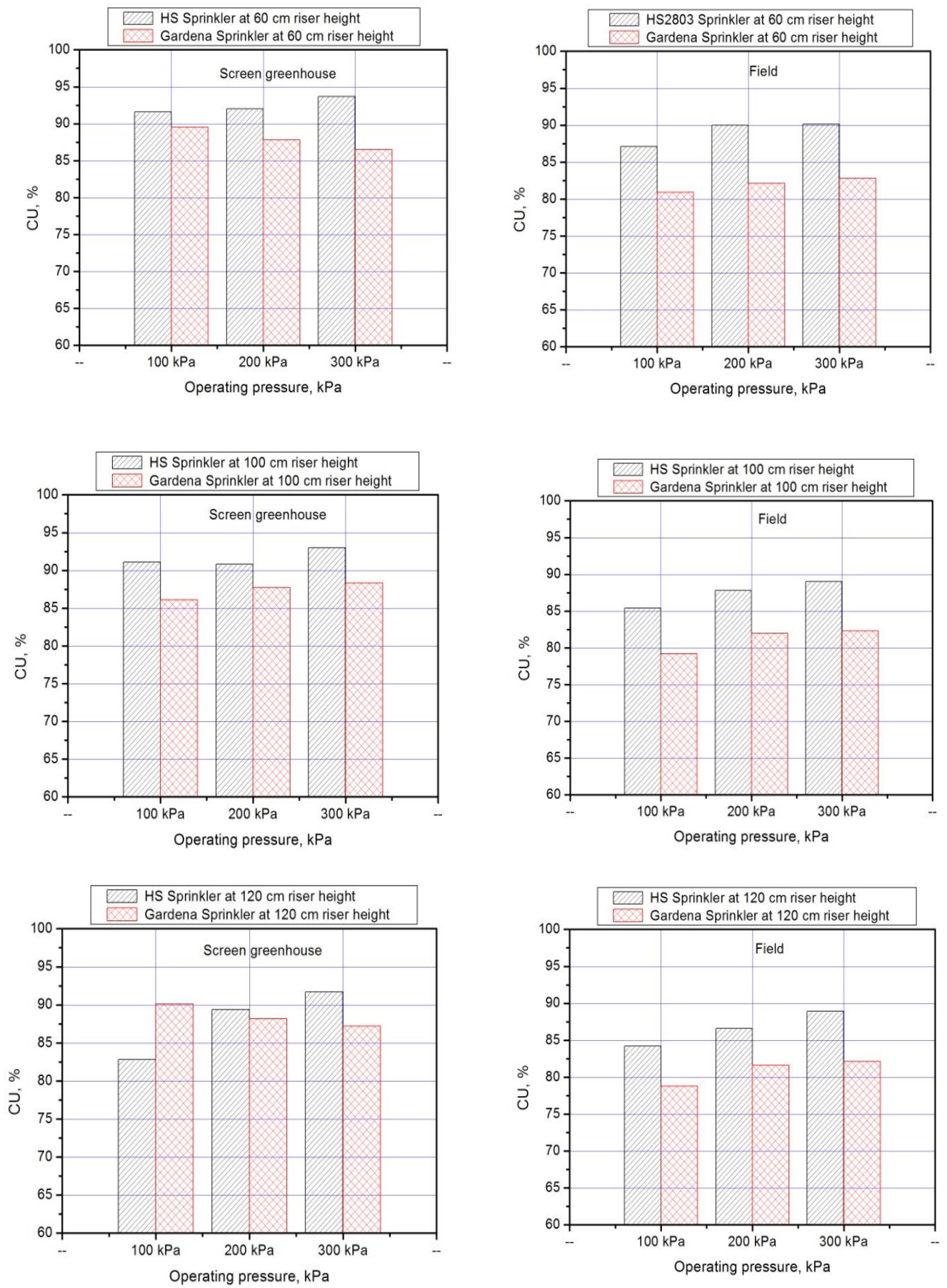

Fig. 3:The effect of type, operating pressure and riser height of sprinkler on the coefficient uniformity (CU) under screen greenhouse and open field conditions, 


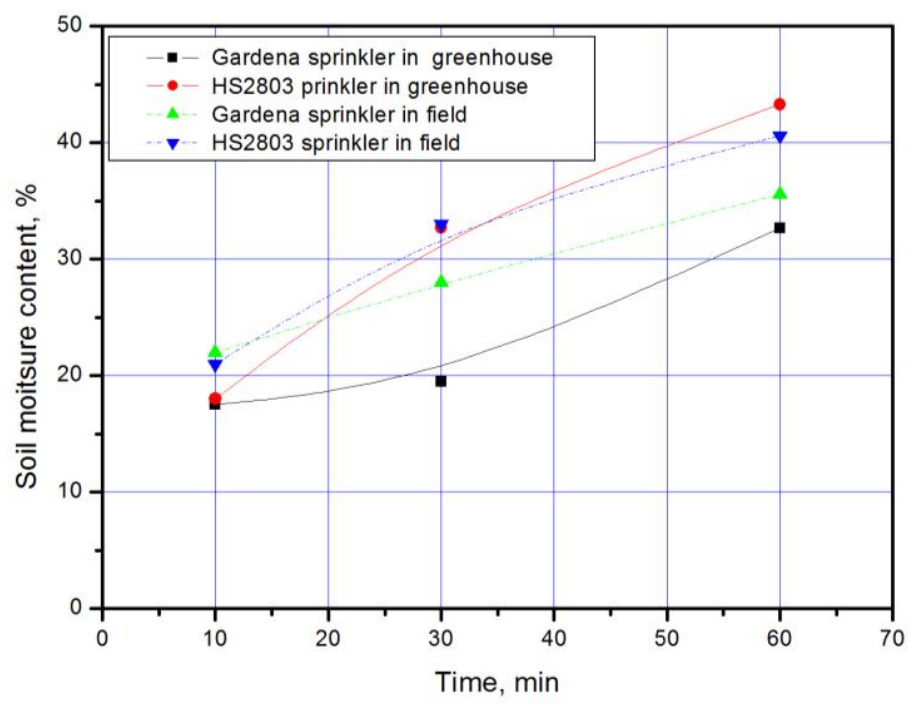

Fig. 4: The soil moisture content for two different types of sprinklers and different operating spray irrigation time under screen greenhouse and soil field conditions.

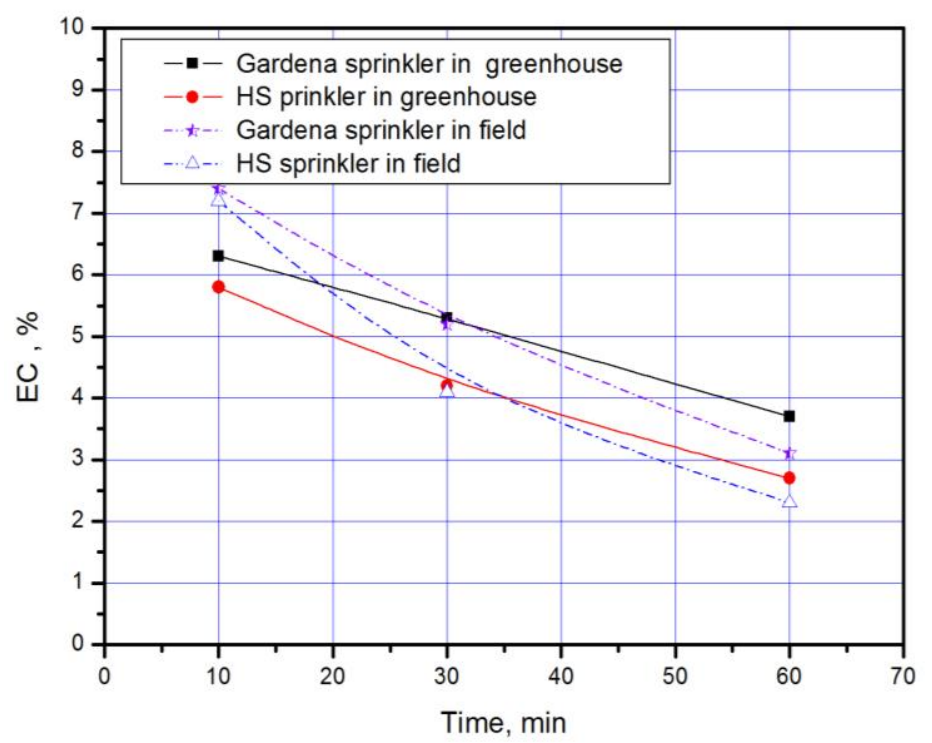

Fig. 5: The soil conductivity for two different types of sprinklers and different operating spray irrigation time under screen greenhouse and soil field conditions. 
Table 6: The effect of sprinkler type, operating pressure and riser height on soil moisture contents percent for greenhouse and field conditions at $10 \mathrm{~cm}$ depth

\begin{tabular}{|c|c|c|c|c|c|}
\hline \multirow{2}{*}{$\begin{array}{c}\text { Operating } \\
\text { pressure, } \\
\mathrm{kPa}\end{array}$} & \multirow{2}{*}{$\begin{array}{c}\text { Riser } \\
\text { height, } \\
\mathrm{cm}\end{array}$} & \multicolumn{2}{|c|}{$\begin{array}{c}\text { Soil moisture } \\
\text { contents in Screen } \\
\text { Greenhouse, }\end{array}$} & \multicolumn{2}{|c|}{$\begin{array}{c}\text { Soil moisture } \\
\text { contents in open field } \\
\%\end{array}$} \\
\cline { 3 - 6 } & $\begin{array}{c}\text { Gardena } \\
\text { Sprinkler }\end{array}$ & $\begin{array}{c}\text { HS2803 } \\
\text { Sprinkler }\end{array}$ & $\begin{array}{c}\text { Gardena } \\
\text { Sprinkler }\end{array}$ & $\begin{array}{c}\text { HS2803 } \\
\text { Sprinkler }\end{array}$ \\
\hline 100 & 60 & 19.4 & 23.0 & 20.6 & 24.1 \\
\hline & 100 & 18.1 & 22.7 & 19.6 & 23.6 \\
\hline & 120 & $\mathbf{1 6 . 9}$ & 20.3 & 18.8 & 20.5 \\
\hline 200 & 60 & 20.5 & 28.8 & 24.1 & 31.5 \\
\hline & 100 & 19.5 & 22.5 & 20.3 & 29.2 \\
\hline & 120 & 17.2 & 20.5 & 19.6 & 25.6 \\
\hline 300 & 60 & 22.6 & 29.8 & 26.7 & 39.6 \\
\hline & 100 & 20.1 & 26.5 & 25.2 & 34.2 \\
\hline & 120 & 18.1 & 24.2 & 20.8 & 30.8 \\
\hline
\end{tabular}

Table 7: The measuring values of water flow rate for both Gardena and HS2803 sprinkler at different operating pressure and riser height for greenhouse and field conditions.

\begin{tabular}{|c|c|c|c|c|c|}
\hline \multirow[b]{2}{*}{$\begin{array}{c}\text { Operating } \\
\text { pressure, } \\
\mathrm{kPa}\end{array}$} & \multirow[b]{2}{*}{$\begin{array}{l}\text { Riser } \\
\text { height, } \\
\text { cm }\end{array}$} & \multicolumn{2}{|c|}{ Screen Greenhouse } & \multicolumn{2}{|c|}{ Open field } \\
\hline & & $\begin{array}{c}\text { Gardena } \\
\text { Sprinkler } \\
\text { flow rate, } \\
1 \text { min }^{-1}\end{array}$ & $\begin{array}{c}\text { HS2803 } \\
\text { Sprinkler } \\
\text { flow rate, } \\
1 \text { min }^{-1}\end{array}$ & $\begin{array}{c}\text { Gardena } \\
\text { Sprinkler } \\
\text { flow rate, } \\
1 \text { min }^{-1}\end{array}$ & $\begin{array}{c}\text { HS2803 } \\
\text { Sprinkler } \\
\text { flow rate, } \\
1 \mathrm{~min}^{-1}\end{array}$ \\
\hline \multirow[t]{3}{*}{100} & 60 & 6.6 & 12.7 & 6.7 & 12.8 \\
\hline & 100 & 6.2 & 10.3 & 6.3 & 10.4 \\
\hline & 120 & 5.9 & 9.2 & 6.0 & 9.3 \\
\hline \multirow[t]{3}{*}{200} & 60 & 7.5 & 13.5 & 7.6 & 13.6 \\
\hline & 100 & 7.3 & 12.7 & 7.5 & 12.8 \\
\hline & 120 & 7.1 & 11.5 & 7.2 & 11.6 \\
\hline \multirow[t]{3}{*}{300} & 60 & 8.1 & 14.0 & 8.3 & 14.1 \\
\hline & 100 & 7.8 & 13.3 & 8.0 & 13.5 \\
\hline & 120 & 5.9 & 10.5 & 6.0 & 10.6 \\
\hline
\end{tabular}


Table 8: The effect of type of sprinkler, operating pressure and riser height on soil conductivity for greenhouse and field conditions

\begin{tabular}{|c|c|c|c|c|c|}
\hline \multirow{2}{*}{$\begin{array}{c}\text { Operating } \\
\text { pressure, } \\
\mathrm{kPa}\end{array}$} & $\begin{array}{c}\text { Riser } \\
\text { height, } \\
\mathrm{cm}\end{array}$ & \multicolumn{2}{|c|}{$\begin{array}{c}\text { Soil conductivity under } \\
\text { Screen Greenhouse, } \\
\mathrm{cmSm}^{-1}\end{array}$} & $\begin{array}{c}\text { Soil conductivity } \\
\text { under Field (no tiled } \\
\text { soil, } \\
\mathrm{cmSm}^{-1}\end{array}$ \\
\cline { 3 - 6 } & & $\begin{array}{c}\text { Gardena } \\
\text { Sprinkler }\end{array}$ & $\begin{array}{c}\text { HS2803 } \\
\text { Sprinkler }\end{array}$ & $\begin{array}{c}\text { Gardena } \\
\text { Sprinkler }\end{array}$ & $\begin{array}{c}\text { HS2803 } \\
\text { Sprinkler }\end{array}$ \\
\hline 100 & 60 & 3.8 & 3.5 & 5.4 & 3.2 \\
\hline & 100 & 4.2 & 3.6 & 5.7 & 3.5 \\
\hline & 120 & 4.6 & 3.7 & 6.1 & 3.8 \\
\hline 200 & 60 & 3.3 & 3.1 & 4.6 & 2.8 \\
\hline & 100 & 4.1 & 3.3 & 4.8 & 3.0 \\
\hline & 120 & 4.1 & 3.4 & 5.1 & 3.1 \\
\hline 300 & 60 & 2.9 & 2.3 & 3.9 & $\mathbf{2 . 1}$ \\
\hline & 100 & 3.2 & 2.6 & 4.1 & 2.4 \\
\hline & 120 & 3.6 & 2.7 & 4.4 & 2.6 \\
\hline
\end{tabular}

\section{REFERENCES}

ASAE Standard: ASAE.S 398.1. 1985. Procedure for sprinkler testing and performance reporting. In: ASAE Standards. ASAE, St. Joseph, MI.

ASAE Standard: ASAE.S 330.1. 1985. Procedure for sprinkler distribution testing for research purposes. In: ASAE Standards. ASAE, St. Joseph, MI.

Brito, R. A. L., and L. S. Willardson. 1982. Sprinkler irrigation uniformity requirements for the elimination of leaching. Transactions of the ASAE 25(5): 1258-1261.

Christiansen, J. E. 1941. Uniformity of application of water by sprinkler systems. Agricultural Engineering March: 89-92.

Hartill, W.F.T., Young, K., Allan, D.J., Henshall, W.R., 1990. Effects of 
temperature and leaf wetness on the potato late blight. N. Z. J. Crop Hort. Sci. 18, 181-184.

Li, J., and M. Rao. 2003. Field evaluation of crop yield as affected by non-uniformity of sprinkler-applied water and fertilizers. Agricultural Water Management 59: 1-13.

Li, J., B. Li, and M. Rao. 2005. Spatial and temporal distributions of nitrogen and crop yield as affected by no nuniformity of sprinkler fertigation. Agricultural Water Management 76: 160-180.

Martin. 2003. Measured and simulated uniformity of low drift nozzle sprinklers. Transactions of the ASAE 46(2): 321-330.

Merriam, J.L. and J. Keller. 1978. Farm irrigation system evaluation: a guide for management. Utah State University, Logan, Utah.

Merriam, J.L., M.N. Shearer. and C.M Burt. 1980. Evaluating irrigation systems and practices. In: Design and Operation of Farm Irrigation Systems (ed. M.E. Jensen) ASAE monograph no. 3 pp. $721-760$.

Mizubuti, E.S.G., Fry, W.E., 1998. Temperature effects on the developmental stages of isolates from three clonal lineages of Phytophthora infestans. Phytopath. 88, 837-843.

Perry, C., and M. D. Dukes. 2004. Effects of variable rate sprinkler cycling on irrigation uniformity. ASAE Paper No. 041117. St. Joseph, Mich.: ASAE.

Schneider, A. D. 2000. Efficiency and uniformity of the LEPA and spray sprinkler methods: A review. Transactions of the ASAE 43(4): 937944.

Tarjuelo, J. M., J. Montero, P. A. Carrion, F. T. Honrubia, and M. A. Calvo. 1999. Irrigation uniformity with medium size sprinklers part II: Influence of wind and other factors on water distribution. Transactions of the ASAE 42(3): 677-689.

Vories, E. and R.D. von Bernuth. 1986. Single nozzle sprinkler performance in wind. Trans. ASAE. 29(5): 1325-1330 


\section{الملغص العربي \\ تقييم رشاش مفرد تحت ظروف الطقس المصرية}

*د. السيد محمود البيلى صحصاح ، ** د/ محمد محمود البيلى ، ***د/ محمود عياد

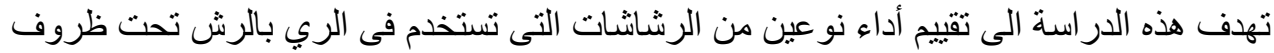
الطقس المصرية ، حيث أجريت هذه الدراسة فى قسم الهندة الزر اعية و محطة بحوث سخاو و بمعهد بحوث المياه و الأراضى ـ و تم أختبار نوعين من الرشاشات أحدهما رشاش نبضى موديل Gardena Impulse sprinkler

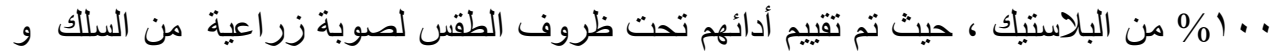

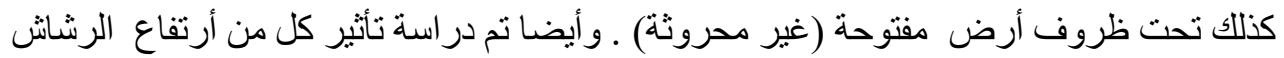

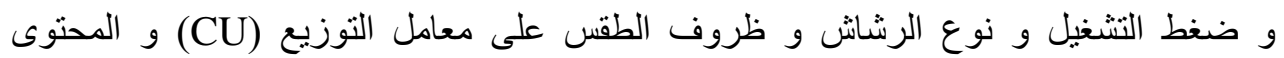

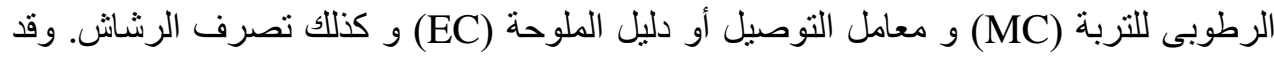

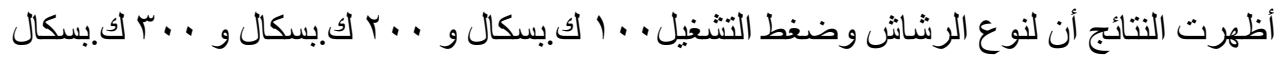

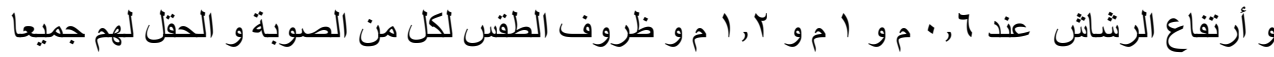

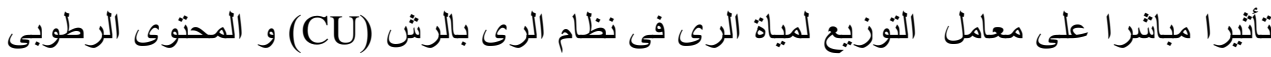

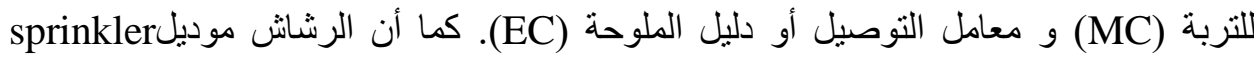
Gardena Impulse sprinkler قد أعطى أفضل أداء مقارنة بالرشاش (CS2803 three arm ، حيث بلغت قيم

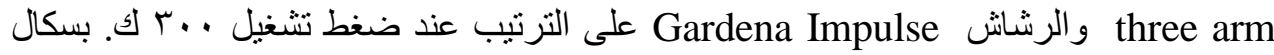

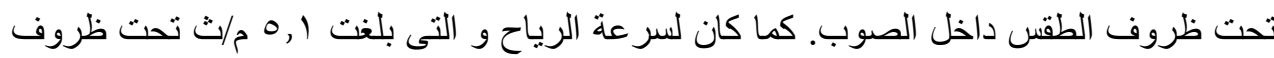

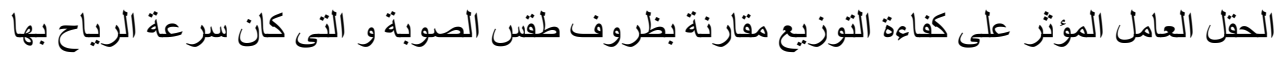

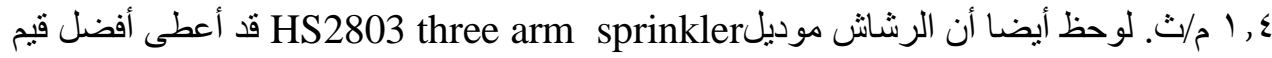

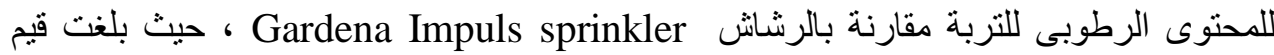

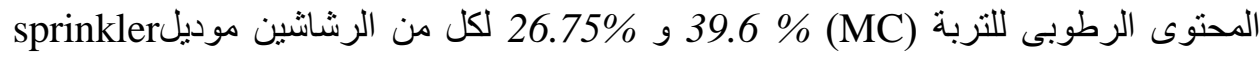
و والرشاش Gardena Impulse على الترتيب عند أقل أرتفاع للرشاش مونش

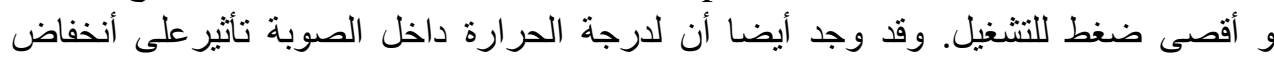
المحتوى الرطوبى فى التربة. أيضا قد أعطى الرشاش

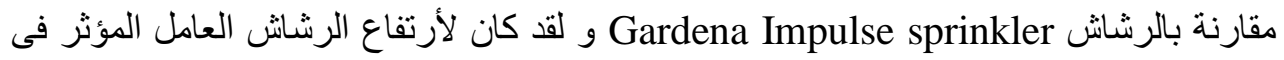
التأثثر على معامل التوصيل و العو امل الأخرى التى تحقق أكبر معدلات مياه و اصلة للتربة.

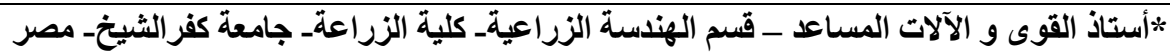

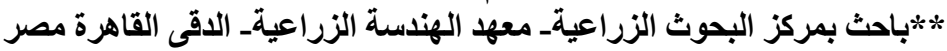

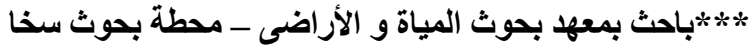

